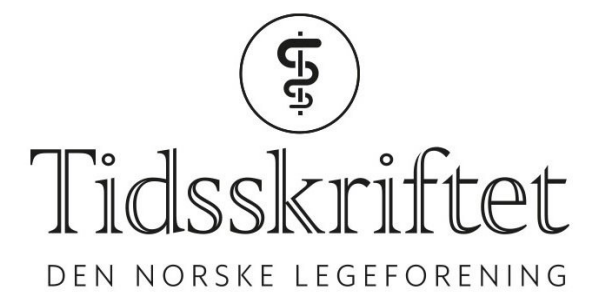

\title{
Er det en lege om bord?
}

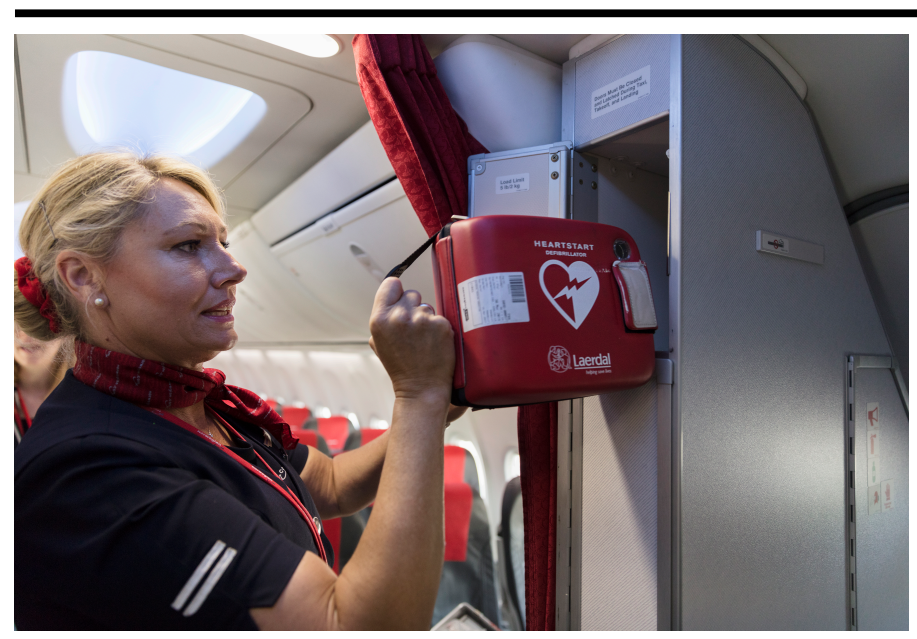

REPORTASJE

LISA DAHLBAK JACOBSEN

E-post: Lisa.Dahlbak.Jacobsen@tidsskriftet.no Tidsskriftet

For mange er det et skrekkscenario med en slik melding over høyttaleren. Brått rives man ut av feriemodus og må melde seg til tjeneste. 


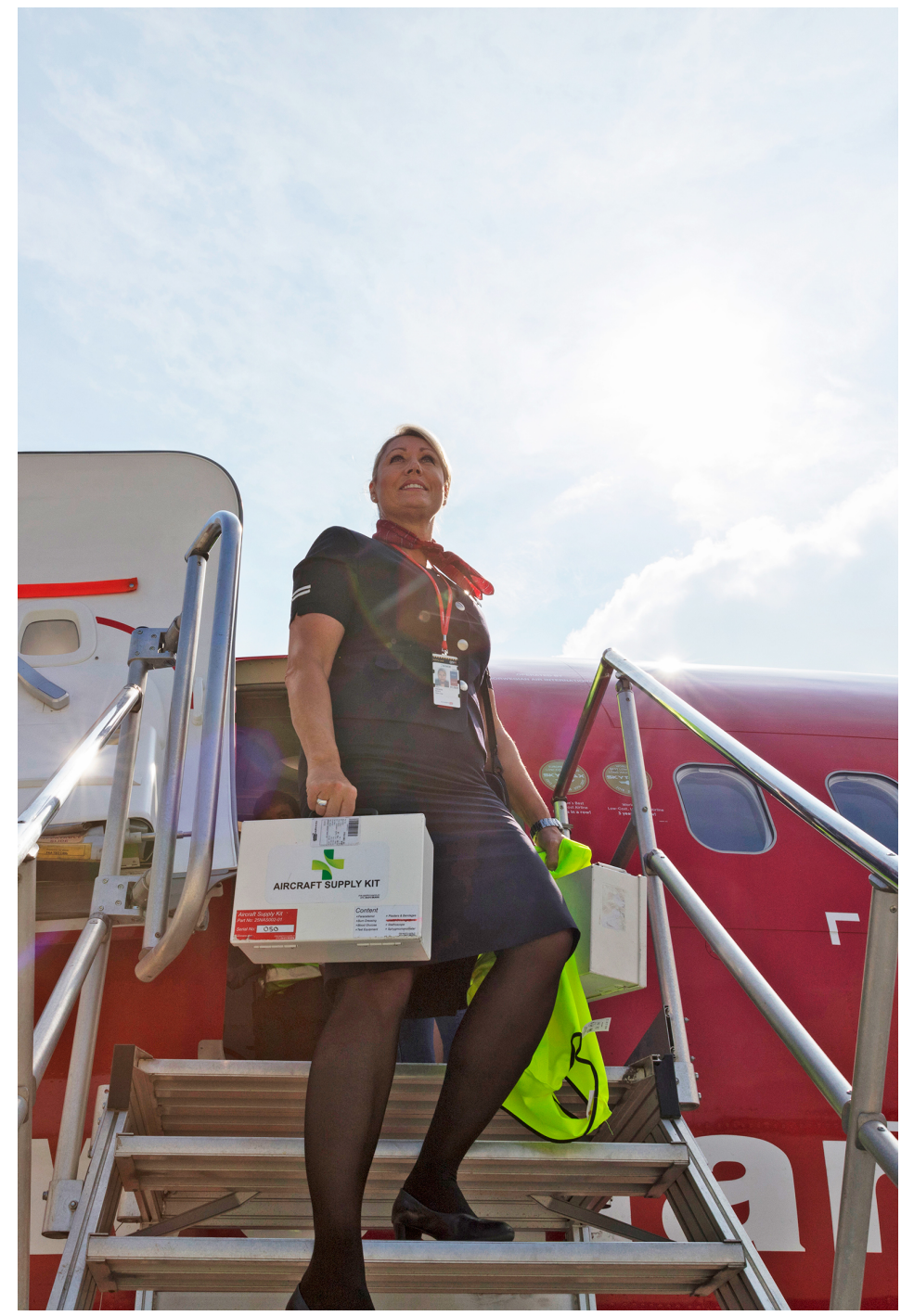

Marlene Sandberg har 26 års erfaring som kabinpersonell, og jobber nå som kabinsjef $i$ Norwegian.

- Jeg har stor forståelse for at leger kan føle at en slik situasjon er ubehagelig. De har jo plikt til å hjelpe, men er i en ukjent situasjon, sier Marlene Sandberg, kabinsjef i Norwegian.

Hun har på sin egen fridag bestemt seg for å hjelpe norske leger med et innblikk i hva som finnes av medisinsk utstyr i norske fly.

Etter en real sikkerhetssjekk av mennesker, besøkskort og bil ruller vi ut til Norwegians egen hangar på Gardermoen, en av hovedbasene til det norske flyselskapet.

I det gigantiske teltet troner flaggskipet Dreamliner, inne til sjekk og teknisk gjennomgang. Ute på plassen foran hangaren står et Boeing 737-8oo-fly, med halehelten Santiago Ramón y Cajal - passende nok en spansk lege som ble tildelt Nobelprisen i fysiologi eller medisin i 1906.

Et slikt fly er arbeidsplassen til kabinsjef Sandberg, og med vante fingre finner hun raskt frem utstyr i smarte hulrom og tilpassede skuffer og skap.

\section{Det store skrinet}

- Her inne i cockpiten står det største skrinet. Det er det vi kaller «Emergency medical kit», sier hun mens hun drar ut skuffen.

Hun tørker seg litt i pannen, men tilværelsen i rekordvarme mai blir straks litt bedre når airconditionanlegget på flyet skrus på.

Det store skrinet står altså inne hos kapteinen, og det er kapteinen som gir tillatelse til bruk. Det internasjonale regelverket krever at det finnes et slikt plombert skrin om bord i alle fly, og det kan kun åpnes av en lege eller sykepleier. Dersom det ikke befinner seg slikt 
helsepersonell om bord, og kabinpersonalet likevel mener at det er behov for utstyr i den, kan man kommunisere med akuttmedisinske sentre som er bemannet med leger utdannet i intensivbehandling og flymedisin. De kan via radio gi råd ved akutte sykdomstilfeller. I disse tilfellene kan kabinpersonalet gi medisin oralt.

- Dette er skrinet vi egentlig ikke vil bruke. Jeg har hatt det fremme to ganger, kommenterer Sandberg.

Av sikkerhetshensyn kan ikke det fullstendige innholdet i skrinet listes opp, men kjapt oppsummert finnes det blant annet nitroglyserin, adrenalin, stesolid, glukose, cetirizin, stetoskop, nåler, skalpell, blodtrykksmåler og et sug. Det finnes også oksygenflasker og masker om bord. I tillegg har Norwegian en hjertestarter på alle sine fly - og akkurat hjertestarteren har Sandberg fått god kjennskap til.

- Kabinpersonalet får svært god opplæring i førstehjelp. I tillegg til førstehjelpskurs under opplæring har vi oppdateringskurs hvert annet år, og før hver flygning har vi en briefing der vi blant annet går gjennom førstehjelp og medisinske akuttsituasjoner. Vi er jo ikke helsepersonell, men vi har god grunnopplæring og mye oppmerksomhet omkring førstehjelp, forteller Sandberg og legger til:

- Forresten er faktisk overraskende mange hos oss sykepleiere også - selv om de selvfølgelig ikke er sykepleiere når de har på seg Norwegian-uniform.

\section{Måtte bruke hjertestarter}

Marlene Sandberg har selv stått midt i en akutt situasjon på en av sine flygninger. Hun var kabinsjef og hadde med seg tre andre ansatte. En passasjer ba om hjelp da ektefellen ikke ville våkne - rett før flyet skulle starte innflygning.

- Den påkalte kabinansatte tilkalte oss andre ved å trykke tre ganger på tilkallingsknappen over setet, forteller Sandberg og demonstrerer.

Sandberg og de andre forsto raskt at passasjeren ikke pustet, og de fant heller ingen puls. Det ble naturlig at hun tok seg av passasjeren, mens de andre spurte etter medisinsk personale, hentet førstehjelpsutstyr og kontaktet cockpiten.

- Den første utfordringen var å få passasjeren med hjertestans ned på gulvet i midtgangen. Vedkommende satt på midterste sete.

En lege og flere sykepleiere befant seg på flyet og meldte seg til tjeneste. Legen tok raskt over kommandoen sammen med en av sykepleierne. Sandberg forteller at de arbeider med å delegere etter et naturlig hierarki: lege, sykepleier, medisinstudent og deretter annet medisinsk personell.

- Utfordringen inne i et fly er plassen. Det er veldig trangt, og legen sa derfor at det holdt med to stykker og meg rundt passasjeren. Legen startet med kompresjoner mens sykepleieren satt oppe ved hodet og utførte innblåsinger. Legen spurte om jeg kunne håndtere hjertestarter, noe jeg bekreftet. Derfor fikk jeg beskjed om å plassere padsene på passasjeren.

\section{Akutt}

Det er heldigvis ikke alltid situasjonen er så akutt. Flyselskapene er vanligvis godt forberedt på å kunne løse problemene. Besetningen har utdanning innen førstehjelp, med særlig søkelys på situasjoner som kan oppstå under flygning. Allergireaksjoner, besvimelser, små skader, forbrenninger og mage-tarm-besvær er vanlige situasjoner kabinpersonalet ofte kan håndtere selv.

- Så når spør dere om hjelp?

- Oftest kun i akutte situasjoner, eller om vi trenger en «second opinion» før vi eventuelt rekvirerer ambulanse som står klar på bakken. Jeg har jobbet som kabinpersonell i 26 år. Jeg 
har kun bedt om medisinsk assistanse tre eller fire ganger. Alle ganger har det befunnet seg kompetente, hyggelige mennesker som har vært positive til å hjelpe. For oss er det veldig godt å vite at det er en lege der. Min erfaring er at det er lett å få leger til å hjelpe til, og vi er veldig takknemlige.
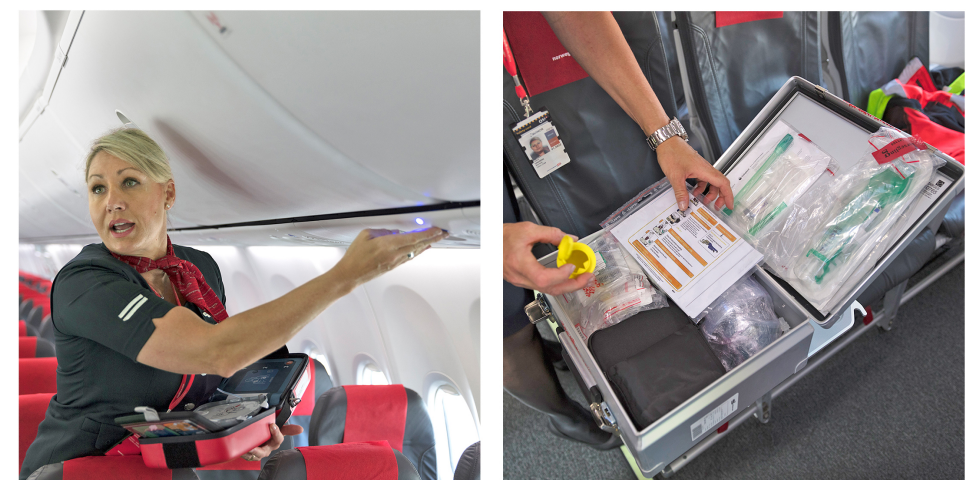

Ved en akuttsituasjon varsler kabinansatte ved å trykke tre ganger på lampen over stolrekken. Ved nødstilfeller og med en lege og kapteinens godkjenning kan det store skrinet «Emergency medical kit» hentes $i$ cockpit.

En av gangene var altså under hjertestansen, hvor også kabinsjefen måtte trå til. Etter at Sandberg hadde koblet pasienten til hjertestarteren, skrudde legen den på.

- Vi holdt oss unna et øyeblikk, og ved første sjokk fra hjertestarteren hostet passasjeren. Det fungerte! Jeg var så lettet. Vedkommende hadde fortsatt svært lav respirasjon, men vi hadde altså fått hjertet til å slå igjen.

Sandberg har sikkert fortalt historien mange ganger før, men blir fortsatt blank i øynene når hun forteller om den store lettelsen - og hvor viktig det er at det finnes hjertestarter $\mathrm{i}$ flyet.

Underveis i prosessen hadde kapteinen fått fri passasje ned til ankomstlufthavnen.

- Vi meldte fra at det var fire personer som landet uten sikkerhetssele. Og flyet gikk altså rett ned - i turbulens, forteller Sandberg og viser med hånden hvor bratt nedstigningsgraden var.

- Jeg satt og holdt fast i passasjeren under nedstigning. Det humpet og danset. Da vi endelig landet, sto en ambulanse klar som tok over all behandling med oksygen og adrenalin.

- Hvordan gikk det med vedkommende?

- Det vet jeg faktisk ikke. Det får vi ikke vite, dessverre. Passasjeren levde da hen kom i ambulansen.

\section{Lege med barn}

Flyselskapene har rutiner for hvordan de håndterer situasjoner der lege eller andre som bistår medisinsk, får avlastning med eventuelle barn eller andre de har ansvar for.

- I tilfellet med hjertestansen hadde legen med seg et barn. En av de ansatte satte seg sammen med barnet for å berolige det under hele prosessen. Det er rutine å påse at ingen blir sittende alene når mor eller far må ile til og hjelpe. 

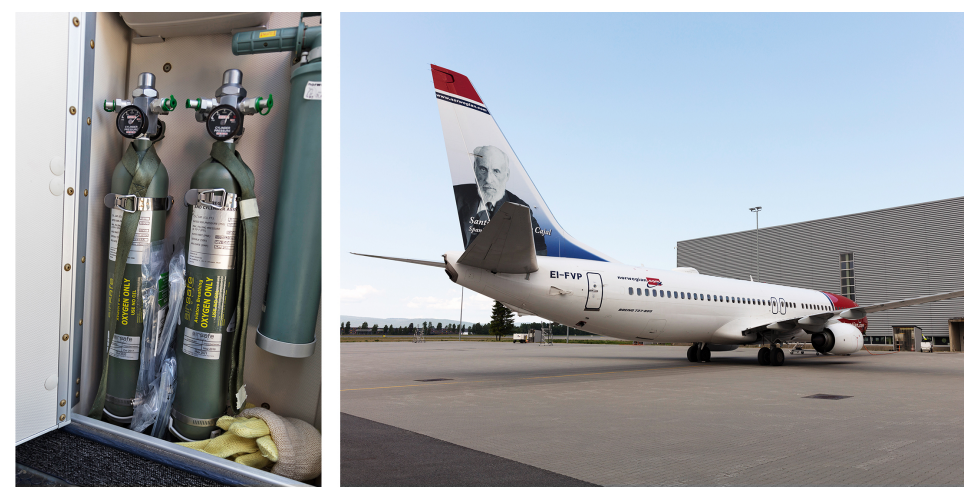

Oksygenflasker og utstyr for å gi oksygentilførsel finnes på fly, også her i flyet som passende nok prydes av halehelt og lege Santiago Ramón y Cajal.

Medisinsk personell som hjelper til under flygninger, blir bedt om å oppgi navnet sitt. Det er for rapportens del, og for at flyselskapet skal kunne kontakte vedkommende som vitne dersom det blir behov. Dessuten sendes det ofte en takk i etterkant av hendelsen.

\section{De ulike «kitene»}

Sandberg er ferdig med å vise frem det store skrinet og løper videre rundt i kabinen og peker og drar frem førstehjelpsutstyr fra alle kriker og kroker.

- Det er viktig at utstyret er plassert flere steder i flyet. På den måten er det aldri langt unna. «First aid kit» finnes det tre av i kabinen. Der er det noen medisiner, men ikke så sterke, branngelé, bandasjer, strips til kutt og natriumklorid blant annet. Det siste er «Aircraft supply kit».

- Dette er det vi bruker mest. Her finnes det blant annet Paracet, blodsukkermåler, saltløsning og plaster.

Dessuten har Norwegian en «First aid bag» som også har et teppe og utstyr til å håndtere oppkast - blant annet et pulver til å legge oppå oppkast. En egen bag kalles «Oxygen equipment bag». Den inneholder masker og ulike nesekatetere som kan kobles til oksygenflaskene som finnes om bord, i tillegg til Ventoline.

- Det er mye å holde styr på?

- Ja, men vi vet hvor alt er, sier hun mens hun møysommelig plukker alle «kiter» og bager opp igjen for å levere det til teknisk som gjennomgår alt utstyr og innhold, plomberer på nytt og plasserer det på eksakt samme sted i flykroppen igjen.

Dermed er alt klart for at flyselskapet og Santiago Ramón y Cajal trygt kan ta med seg passasjerer ut i det blå.

Publisert: 26. juni 2018. Tidsskr Nor Legeforen. DOI: 10.4045/tidsskr.18.0492

(C) Tidsskrift for Den norske legeforening 2020. Lastet ned fra tidsskriftet.no 